\title{
Surgical management of ectrodactyly in a dog
}

\section{Tratamento cirúrgico de ectrodactilia em um cão}

\author{
Márcio Poletto Ferreira $^{1 *}$; Marcelo Meller Alievii ${ }^{1}$; Isis dos Santos Dal-Bó2; \\ Fernanda Silveira Nóbrega ${ }^{2}$; Paula Cristina Sieczkowski Gonzalez 3 ; \\ Carlos Afonso de Castro Beck ${ }^{1}$
}

\begin{abstract}
Ectrodactyly is the term used to designate cases in which soft and bone tissue separation within the distal region of the thoracic limbs is present. It is observed in particular below the metacarpal bones and extending to the radius and ulna. In addition, it can often be associated with ipsilateral elbow luxation. We describe a case of ectrodactyly in a 3-month-old mongrel dog, where bone and soft tissue separation occurred between the third and fourth digits, extending proximally to the carpal region. We identified shortening of the ulna without elbow luxation. The dog was subjected to a surgical procedure comprising bone and soft tissue reconstruction and ulnar diaphyseal osteotomy, which was fixed using a Steinmann pin in the intramedullary canal, maintaining a distance of $1 \mathrm{~cm}$ between the two ulnar fragments. Two distal phalanges were removed because it was not possible to reposition them anatomically in the limb. The dog walked with mild lameness nine months after surgery.
\end{abstract}

Key words: Malformation. Canine. Orthopedics. Congenital. Radius. Ulna.

\section{Resumo}

Ectrodactilia é o termo utilizado para designar aqueles casos em que há separação dos tecidos moles e ósseos na região distal dos membros torácicos, podendo ocorrer abaixo dos ossos metacarpianos e estender-se até o rádio e a ulna, além de estar associada, com frequência, à luxação úmero-rádioulnar ipsilateral. Descreve-se um caso de ectrodactilia em canino sem raça definida com três meses de idade, onde foi verificada a separação óssea e dos tecidos moles entre o terceiro e o quarto dígito, estendendo-se proximalmente até a região do carpo, sendo identificado encurtamento da ulna, porém sem luxação do cotovelo. O paciente foi submetido ao procedimento cirúrgico para reaproximação óssea e dos tecidos moles, com ostectomia na diáfise da ulna, a qual fora estabilizada com a utilização de um pino de Steinmann no canal intramedular, permanecendo uma distância de um centímetro entre os dois fragmentos da ulna. As duas falanges distais foram removidas, devido ao fato de não ser possível seu reposicionamento anatômico no membro. Com oito meses de pós-operatório, o animal apresentava deambulação com leve claudicação.

Palavras-chave: Malformação. Canino. Ortopedia. Congênito. Rádio. Ulna.

\footnotetext{
${ }^{1}$ Profs. Drs., Departamento de Medicina Animal, Faculdade de Veterinária, Universidade Federal do Rio Grande do Sul, FAVETUFRGS, Porto Alegre, RS, Brasil. E-mail: marcio.ferreira@ufrgs.br; marcelo.alievi@ufrgs.br; carlos.afonso@ufrgs.br

2 Discentes de Pós-Graduação, Departamento de Cirurgia, Faculdade de Medicina Veterinária e Zootecnia, Universidade de São Paulo, FMVZ-USP, São Paulo, SP, Brasil. E-mail: idb_vet@yahoo.com.br; fernandanobrega.vet@gmail.com

${ }^{3}$ Médica Veterinária, Hospital de Clínicas Veterinárias, Faculdade de Veterinária, Universidade Federal do Rio Grande do Sul, HCV-FAVET-UFRGS, Porto Alegre, RS, Brasil. E-mail: maxpcsg@yahoo.com.br

* Auhor for corrrespondence
} 


\section{Introduction}

Ectrodactyly is the term used to designate cases in which bone and soft tissue separation occurs within the distal region of the thoracic limbs (BARRAND, 2004). This alteration is also known as split-hand deformity, lobster claw deformity, oligodactyly, and hypodactyly (CARRIG et al., 1981). Separation of the medial and lateral regions occurs within the limb, which can start distally at the metacarpal bones and extend to the radius and ulna. It can occur unilaterally (HARASEN, 2010) or bilaterally (CARVALHO et al., 2011). Ectrodactyly may be associated with the absence and hypoplasia of several carpal and metacarpal bones, finger duplication, metacarpal synostosis, and elbow luxation (CARRIG et al., 1981; OLIVEIRA; ARTONI, 2002). There are reports of this disease in dogs (CARRIG et al., 1981; INNES et al., 2001; BARRAND, 2004; HARASEN, 2010), cats (MACRÍ et al., 2009), birds, monkeys, rats (COOPER et al., 1990), humans (SHANSKE et al., 2010), and cattle (MONTGOMERY et al., 1989). The surgical techniques used to correct this defect include pancarpal arthrodesis (KELLER; CHAMBERS, 1989), arthrodesis combined with ulnar osteotomy or ostectomy (INNES et al., 2001; HARASEN, 2010), and soft tissue reconstruction (BARRAND, 2004; LEIGHTON, 1983), while some surgeons choose to amputate the limb when the condition is unilateral (BINGEL; RISER, 1977; PRATSCHKE, 1996). Among the different ways used to evaluate the results of surgical treatment, subjective evaluation of support (degree of claudication) is important (FERREIRA, 2013). This study aimed to describe a case of surgically corrected ectrodactyly in a dog.

\section{Case report}

A 3-month-old female mongrel with a history of lameness due to congenital deformity in the left thoracic limb was treated at Hospital de Clínicas Veterinárias da Universidade Federal do Rio Grande do Sul. Clinical (Figure 1A) and radiographic examination showed bone and soft tissue separation between the third and fourth digits, extending proximally to the carpal region. We observed ulnar shortening when compared to the radius; however, there was no elbow luxation. The dog was subjected to a surgical procedure to reconstruct the bone and soft tissues, followed by ulnar diaphyseal osteotomy. The ulnar ostectomy was fixed by inserting a $2.5-\mathrm{mm}$ wide Steinmann pin into the intramedullary canal, maintaining a distance of 1 $\mathrm{cm}$ between the two ulnar fragments (Figure 1B). Two distal phalanges (the second and third digits) were removed (Figure 2A). Three months after surgery, the dog exhibited adequate radiographic signs of ulnar healing as well as V degree lameness when using the operated limb (halting use of the limb to walk), on a scale from I (animal does not remain standing) to VII (uses the limb without any restriction) (FERREIRA, 2013). Nine months after surgery, radiographic examination showed ostectomy healing and adequate bone positioning of the left thoracic limb (Figures 1C and D). The dog exhibited continuous use of the limb with mild lameness (V degree) due to the small difference in length between the limbs (Figure 2B).

Preoperatively, the dog was subjected to 8 hours of fasting from water and food and received meperidine $^{4}(2 \mathrm{mg} / \mathrm{kg} \mathrm{IM})$ and acepromazine ${ }^{5}(0.1$ $\mathrm{mg} / \mathrm{kg}$ IM) as pre-anesthetic medication. After 15 minutes, anesthesia was induced with propofol ${ }^{6}$ (4 $\mathrm{mg} / \mathrm{kg} \mathrm{IV)}$ and general anesthesia was maintained with isoflurane ${ }^{7}$ in an open system. Postoperatively, the dog received meloxicam ${ }^{8}(0.2 \mathrm{mg} / \mathrm{kg}$ SID) for seven days and tramadol ${ }^{9}(3 \mathrm{mg} / \mathrm{kg}$ TID) for three days as analgesic medication. Cephalexin ${ }^{10}(30 \mathrm{mg} /$ $\mathrm{kg}$ BID) was administered as antimicrobial therapy for ten days. The operated limb remained bandaged for four weeks and controlled walks were allowed once the bandage had been removed.

\footnotetext{
${ }^{4}$ Dolosal, Cristália

${ }^{5}$ Acepran, Jofadel

${ }^{6}$ Provive, Clarís

${ }^{7}$ Forane, Abbott

${ }^{8}$ Meloxivet, Duprat

9 Tramadol, Cristália

${ }^{10}$ Relexine, Virbac
} 
Figure 1. Congenital deformity described as ectrodactyly in the left thoracic limb of a 3-month-old mongrel dog. A) Deformity at the distal end of the left thoracic limb. Note separation in the distal portion of the left thoracic limb (black arrow). B) Immediate postoperative radiographic examination of the corrected ectrodactyly in the mediolateral projection. Note the intramedullary position of the Steinmann pin (white arrow) and separate ulnar diaphysis (blue arrow). C and D) Radiographic examination of the left thoracic limb 9 months after surgery in the mediolateral (C) and craniocaudal projections (D). Ulnar elongation obtained after the surgical procedure was not sufficient to avoid unevenness of the carpal bones.

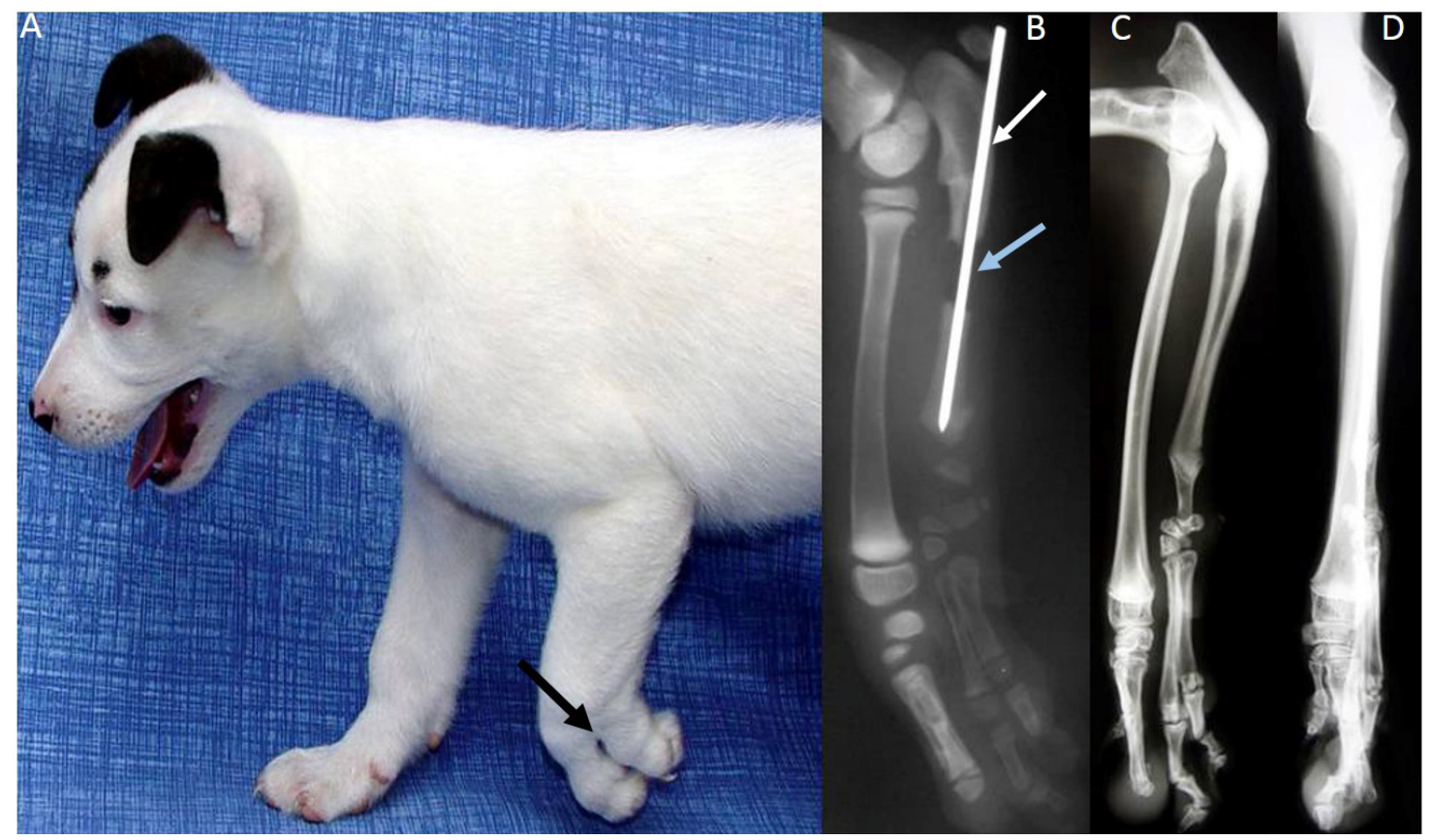

Figure 2. Mongrel canine with ectrodactyly in the left thoracic limb. A) Immediately after surgical correction. B) Nine months after surgical treatment.

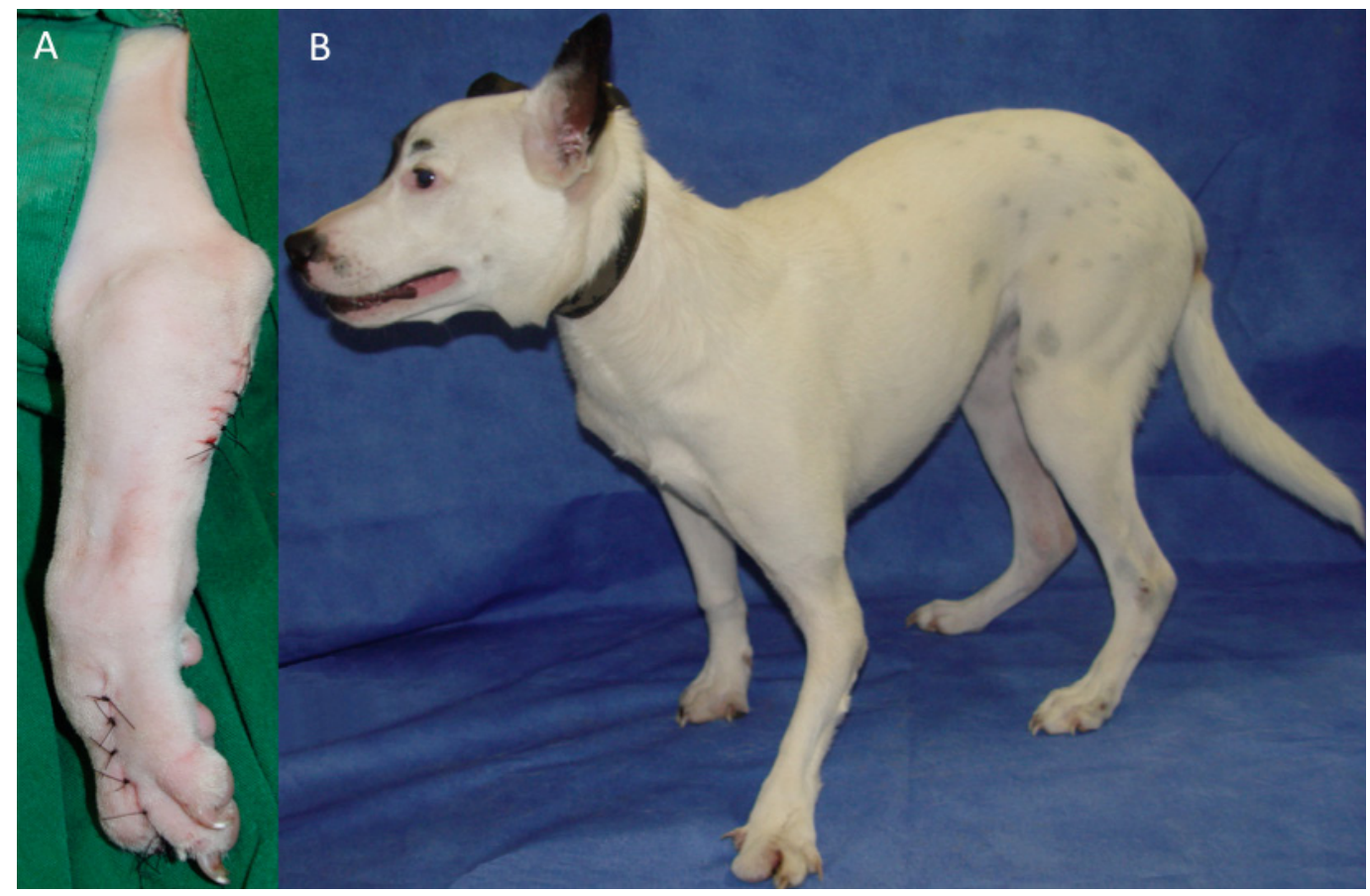


Intrinsic malformation or alteration in the development of mesenchymal bone cells between 23 and 25 days gestation leads to limb abnormalities including ectrodactyly. Several factors can cause these alterations, including genetic mutation, diet, drugs, vaccines, and radiation (TOWLE; BREUR, 2004). Ectrodactyly is associated with the heritability of an autosomal dominant gene in cats; however, this relationship has not yet been established in dogs. Ectrodactyly was not observed in any of the close relatives of the dog described in the current report. No congenital alteration other than ectrodactyly was noted. This is common in humans, where an alteration of the limbs may be associated with ectodermal dysplasia and cleft palate (INNES et al., 2001).

Although it is possible to diagnose ectrodactyly through clinical examination, radiographic examination was essential to confirm shortening of the ulna in the dog described in the present report. The type of alteration found affects the choice of therapy, as when there are no severe bone defects, such as the absence of bones or significant shortening, only reconstruction of the soft and bone tissues is performed. However, in more severe cases, arthrodesis is often required and amputation of the limb may be an option (FREY; WILLIAMS, 1995). Carpal arthrodesis is the most commonly adopted procedure (INNES et al., 2001). As the dog described here presented no bone deformities, performing this procedure was not necessary.

Separation of the limb up to the carpus is rare, as observed in the 19 cases of ectrodactyly described in dogs (CARRIG et al., 1981; INNES et al., 2001). In these cases, soft and bone tissue separation most often involved only the metacarpus. Although concomitant ipsilateral elbow luxation might occur in animals with ectrodactyly (CARRIG et al., 1981), this alteration was not observed in our dog. Elbow luxation seems to be due to ectrodactyly, rather than the contrary (BARRAND, 2004), as indicated by the low frequency of reports of ectrodactyly in dog breeds with a predisposition for congenital elbow luxation such as Pekingese, Toy Poodles, Pugs, Chihuahuas, Pinschers, Dachshunds, and Yorkshire Terriers, and reinforced by our case of ectrodactyly in which elbow luxation was not observed.

In the current case, the choice to perform conservative treatment (without limb amputation) within the carpal region and digits was based on the presence of only slight, or even partial, radiographic evidence of altered bone structure and the possibility for aesthetic and functional recovery of the limb, which is consistent with the treatment options recommended in the scientific literature (BARRAND, 2004). Among the techniques cited in the scientific literature, such as carpal arthrodesis (KELLER; CHAMBERS, 1989; HARASEN, 2010), soft tissue reconstruction (LEIGHTON, 1983; BARRAND, 2004), arthrodesis with ulnar ostectomy or osteotomy (INNES et al., 2001; HARASEN, 2010), and metacarpal synostosis (PISONI et al., 2014), ulnar ostectomy was chosen and fixed with an intramedullary pin and bandage to provide better postoperative comfort, although this combination is not always necessary (TURNER et al., 1998). This technique allows for greater limb growth, thereby decreasing the difference in length between the thoracic limbs, which was lower than $2 \mathrm{~cm}$ in the case reported here. Due to the small difference in size between the limbs, the dog exhibited frequent support of the operated limb, which may not have occurred if the limb had been very significantly shortened (LEIGHTON, 1983). However, according to radiographic examination, the elongated ulna obtained after the surgical procedure was not sufficient to prevent unevenness of the carpal bones. Carpal arthrodesis has been used successfully in various animals (INNES et al., 2001; HARASEN, 2010); however, in our case there was no need to perform this surgery as the dog did not exhibit instability or pain in the carpus, and presented only a limited range in the flexion and extension movements of this joint. Two distal phalanges were removed as it was not possible to position them anatomically in the limb; this would 
have hindered the animal's support and caused abrasion damage, as observed by Ferreira et al. (2007).

According to Carrig et al. (1981), the main changes found in dogs with ectrodactyly are bone hypoplasia, soft tissue contracture, and bone fusion (syndactyly). In this report, the dog only exhibited shortening of the ulna. The owner was instructed to castrate the dog because of the likely hereditary nature of the disease (MONTGOMERY et al., 1989; FREY; WILLIAMS, 1995).

We conclude that treatment comprising soft and bone tissue reconstruction combined with ostectomy of a diaphyseal segment of the ulna was efficient in allowing the aesthetic and functional recovery with lameness (V degree) of the left thoracic limb in a dog with ectrodactyly.

\section{References}

BARRAND, K. R. Ectrodactyly in a west highland white terrier. Journal of Small Animal Practice, Chicago, v. 45, n. 6, p. 315-318, 2004.

BINGEL, S. A.; RISER, W. H. Congenital elbow luxation in the dog. Journal of Small Animal Practice, Chicago, v. 18, n. 7, p. 445-456, 1977.

CARRIG, C. B.; WORTMAN, J. A.; MORRIS, E. L.; BLEVINS, W. E.; ROOT, C. R.; HANLON, G. F.; SUTER, P. F. Ectrodactyly (split-hand deformity) in the dog. Veterinary Radiology and Ultrasound, Chicago, v. 22, n. 3, p. 123-144, 1981.

CARVALHO, F. R.; DOMÍNGUEZ, A. S.; MORALES, P. C. Bilateral ectrodactyly and spinal deformation in a mixed-breed dog. Canadian Veterinary Journal, Ottawa, v. 51, n. 1, p. 47-49, 2011.

COOPER, J. E.; PURTON, P.; POSWILlO, D. E. A lobster claw abnormality in the common marmoset (Callithrix jacchus). Laboratory Animals, London, v. 24, n. 2, p. 151-155, 1990.

FERREIRA, M. P. Comparação das técnicas de osteotomia para avanço da tuberosidade tibial (TTA) e nivelamento do platô tibial (TPLO) para correção de ruptura do ligamento cruzado cranial em cães com o sistema de baropodometria. 2013. Tese (Doutorado em Clínica Cirúrgica) - Faculdade de Medicina Veterinária e Zootecnia. Universidade de São Paulo, São Paulo.
FERREIRA, M. P.; ALIEVI, M. M.; BECK, C. A. C.; VOLL, J.; MUCCILLO, M. S.; GOMES, C. Ectrodactilia em cão: relato de caso. Arquivo Brasileiro de Medicina Veterinária e Zootecnia, Belo Horizonte, v. 59, n. 4, p. 910-913, 2007.

FREY, M.; WILLIAMS, J. What is your diagnosis? (Ectrodactyly in a Chow Chow dog). Journal of American Veterinary Medical Association, Schaumburg, v. 206, n. 5, p. 619-620, 1995.

HARASEN, G. Surgical management of ectrodactyly in a Siberian husky. Canadian Veteterinay Journal, Ottawa, v. 51, n. 4, p. 421-424, 2010.

INNES, J. F.; MCKEE, W. M.; MITCHELL, R. A. S.; LASCElleS, B. D. X.; JOHNSON, K. A. Surgical reconstruction of ectrodactyly deformity in four dogs. Veterinary Comparative Orthopaedics and Traumatology, Stuttgart, v. 14, n. 4, p. 201-209, 2001.

KELLER, W. G.; CHAMBERS, J. N. Antebraquial metacarpal arthrodesis for fusion of deranged carpal joints in two dogs. Journal of American Veterinary Medical Association, Schaumburg, v. 195, n. 10, p. 13821384, 1989.

LEIGHTON, R. L. Surgical repair of a congenital defect of the radius, ulna, and carpus in a dog. Modern Veterinary Practice, Wheaton, v. 64, n. 1, p. 41-44, 1983.

MACRÍ, F.; DE MAJO, M.; RAPISARDA, G.; MAZZULLO, G. Two cases of feline ectromelia: autopodium ectromelia associated with humero-ulnar synostosis and zeugopodium ectromelia. Journal of Feline Medicine and Surgery, London, v. 11, n. 8, p. 731734, 2009.

MONTGOMERY, R. D.; MILTON, J. L.; MANSFIELD, P. D.; HUDSON, J. A. What is your diagnosis? (Ectrodactyly in a dog). Journal of American Veterinary Medical Association, Schaumburg, v. 194, n. 1, p. 120121, 1989.

OLIVEIRA, D.; ARTONI, S. M. B. Ectrodactilia em cão (Canis domestica). Ciência Rural, Santa Maria, v. 32, n. 6, p. 1063-1065, 2002.

PISONI, L.; DLE MAGNO, S.; CINTI, F.; DALPOZZO, B.; BELLEI, E.; CLORITI, E.; JOECHLER, M. Surgical induction of metacarpal synostosis for treatment of ectrodactyly in a dog. Veterinary Comparative Orthopaedics and Traumatology, Stuttgart, v. 27, n. 2, p. 166-171, 2014.

PRATSCHKE, K. A case of ectrodactyly in a dog. Irish Veterinary Journal, London, v. 49, n. 7, p. 412-413, 1996.

SHANSKE, A. L.; YACHELEVICH, N.; ALA-KOKKO, L.; LEONARD, J.; LEVY, B. Wolf-Hirschhorn syndrome 
and ectrodactyly: new findings and a review of the literature. American Journal of Medical Genetics Part A, Hoboken, v. 152A, n. 1, p. 203-208, 2010.

TOWLE, H. A. M.; BREUR, G. J. Dystoses of the canine and feline appendicular skeleton. Journal of American Veterinary Medical Association, Schaumburg, v. 225, n. 11, p. 1685-1692, 2004.
TURNER, B. M.; ABERCROMBY, R. H.; INNES, J.; McKEE, W. M.; NESS, M. G. Dynamic proximal ulnar osteotomy for the treatment of ununited anconeal process in 17 dogs. Veterinary Comparative Orthopaedics and Traumatology, Stuttgart, v. 11, n. 2, p. 76-79, 1998. 